\title{
PENGUKURAN TINGKAT EFEKTIVITAS ADUAN WARGA MENGENAI INDIKASI PELANGGARAN PERDA MENGGUNAKAN ALGORITMA C45
}

\section{Fahrudin dan Sugiarto}

Politeknik Purbaya Tegal Jawa Tengah, Indonesia

Email: fahrudin.purbaya@gmail.com dan bluej231@gmail.com

\begin{abstract}
Abstact
This research aims to understand how to improve the system that runs, namely complaints manually through whatsapp that are at risk of loss of historical data because it is not yet integrated with the database. The research method used is a quantitative approach in analyzing the effectiveness of online complaints applications.. With this application, it is hoped that the community can actively participate as informants and provide suggestions for things that need to be improved and perfected. The research location is in the office of the Civil Service Police Unit (Sat Pol PP) and the citizen input data is processed using the C4.5 algorithm to be used as a reference in the conclusion of the quality/quality of public services. The data used to design this decision tree consists of 1 special attribute (citizen_valuation attribute) and 3 regular attributes (response, process, and completion). To make data analysis using the C4.5 Algorithm using 50 sample data and 10 test data selected. From the results obtained, it can be seen that the decision tree model of the citizen satisfaction index of services has an accuracy value of $90.00 \%$, with $90 \%$ precision and $100 \%$ Class recall. From this test, it was concluded that the level of effectiveness of citizen complaints was quite good, the response and attention from the government in this case the Sat Poll PP of Tegal district was quite good.
\end{abstract}

Keywords: Algoritm C4.5; Decision Tree; Public Complaints; Online Complaints; Tegal; Sat Pol PP

\footnotetext{
Abstrak

Penelitian ini bertujuan untuk memahami cara memperbaiki sistem yang berjalan yakni pengaduan secara manual melalui whatsapp yang riskan terhadap hilangnya data histori dikarenakan belum terintegrasi dengan database. Metode penelitian yang digunakan adalah pendekatan kuantitatif dalam menganalisa keefektivitasan aplikasi pengaduan online. Dengan adanya aplikasi ini diharapkan masyarakat dapat berpartisipasi aktif sebagai informan maupun saran terhadap hal yang perlu untuk diperbaiki dan disempurnakan. Lokasi penelitian di kantor dinas Satuan Polisi Pamong Praja (Sat Pol PP) dan data masukan warga diolah menggunakan algoritma C4.5 untuk dijadikan referensi dalam kesimpulan mutu/kualitas layanan publik. Data yang digunakan untuk merancang pohon keputusan ini terdiri dari 1 special atribut (atribut penilaian_warga) dan 3 atribut regular (respon, proses dan penyelesaian). Untuk membuat analisa data menggunakan Algoritma C4.5 dengan menggunakan 50 data sampel dan dipilih 10 data uji. Dari hasil yang didapatkan
} 
terlihat bahwa model pohon keputusan index kepuasan warga terhadap layanan memiliki tingkat nilai akurasi sebanyak $90.00 \%$, dengan presisi $90 \%$ dan Class recall $100 \%$. Dari pengujian tersebut disimpulkan bahwa tingkat efektivitas aduan warga cukup baik, respon dan perhatian dari pihak pemerintah dalam hal ini Sat Poll PP kabupaten Tegal cukup baik.

Kata kunci: Algoritma C4.5; Pohon Keputusan; Aduan Masyarakat; Aduan Online; Kabupaten Tegal; Sat pol pp

\section{Pendahuluan}

Kabupaten Tegal pada khususnya melalui pemerintah daerah beserta jajarannya telah berusaha untuk melayani masyarakat dengan sebaik-baiknya. Namun lazimnya dalam suatu pasti ada kekurangan, begitu juga dalam pembangunan di kabupaten Tegal. Dari itulah muncul satu ide untuk melengkapi kekurangan layanan yang mungkin terjadi yaitu dengan menrancang suatu sistem pengaduan masyarakat. Pengaduan masyarakat ini dijadikan sebagai sarana dalam memberi informasi mengenai indikasi pelanggaran perda, juga sebagai saran bagi pemerintah guna menerapkan pembangunan yang sedang dan akan dijalankan degan harapan lebih optimal dan berdayaguna serta tepat sasaran. Dalam sistem yang telah berjalan sebelumnya, sistem aduan lakukan melalui media sosial seperti twitter dan whatapp sehingga masih cukup banyak kendala. Diantaranya adalah pihak pelapor seringkali tidak jelas identitasnya, subjek atau objek yang dilaporkan seringkali kurang detil, sulit dikoordinasikan dikarenakan belum terintegrasi dengan database. Maka dari itu, pada penelitian ini penulis merancang sistem yang terlah teritergrasi database dan dapat diakses secara online. Sedangkan untuk analisa data menggunakan algoritma pohon keputusan $\mathrm{C} 4.5$ yang sudah terbukti handal dan sering digunakan oleh para peneliti.

Layanan publik adalah segala bentuk jasa pelayanan, baik dalam bentuk barang publik maupun jasa publik yang pada prinsipnya menjadi tanggung jawab dan dilaksanakan oleh Instansi Pemerintah di Pusat, di Daerah, dan di lingkungan Badan Usaha Milik Negara atau Badan Usaha Milik Daerah, dalam rangka upaya pemenuhan kebutuhan masyarakat maupun dalam rangka pelaksanaan ketentuan peraturan perundang-undangan (Ratminto, 2005).

Pengaduan masyarakat adalah bentuk penerapan dari pengawasan masyarakat yang disampaikan oleh masyarakat kepada aparatur pemerintahan terkait berupa sumbangan pikiran suara, gagasan, keluhan ,pengaduan, yang bersifat membangun (Napitupulu, 2007). Pengaduan tersebut marupakan bagian dari pelayanan publik, di mana masyarakat dapat menyampaikan keluhan maupun saran perbaikan terhadap pelayanan yang diberikan (Mahmudi, 2013). Berbagai pelayanan publik memang kerap kali dirasa masih memiliki kekurangan, bahkan sampai gagal berfungsi (Ratminto, 2005). Berdasarkan prinsip pelayanan sebagaimana telah ditetapkan dalam Keputusan Menteri PAN Nomor: 63/KEP/M.PAN/7/2003 tentang Pedoman Umum Penyelenggaraan Pelayanan Publik, yang kemudian dikembangkan menjadi 14 unsur 
yang relevan, valid dan reliabel, sebagai unsur minimal yang harus ada untuk dasar pengukuran Indeks Kepuasan Masyarakat (Etkisyan \& Manar, 2018).

Pengertian Data Mining (Jiawei \& Kamber, 2001), mendefinisikan data mining sebagai proses untuk mendapatkan informasi yang berguna dari gudang basis data yang besar. Data mining adalah proses mencari pola atau informasi menarik dalam data terpilih dengan menggunakan teknik atau metode tertentu. Teknik-teknik, metodemetode, atau algoritma dalam data mining sangat bervariasi. Pemilihan metode atau algoritma yang tepat sangat bergantung pada tujuan dan proses Knowledge Discovery in Database (KDD) secara keseluruhan (Suntoro, 2019). Data mining juga dapat diartikan sebagai pengekstrakan informasi baru yang diambil dari bongkahan data besar yang membantu dalam pengambilan keputusan. Istilah data mining kadang disebut juga knowledge discovery (Prasetyo, 2012).

Algoritma C4.5 merupakan algoritma data mining yang dapat digunakan untuk membentuk pohon keputusan yang merupakan metode klasifikasi yang cukup populer bagi kalangan peneliti.Secara khusus,data mining menggunakan ide-ide seperti pengambilan contoh, estimasi, dan pengujian hipotesis dari statistika dan algoritma pencarian, teknik pemodelan, dan teori pembelajaran dari kecerdasan buatan, pengenalan pola, dan machine learning (Vulandari, 2017). Data mining juga telah mengadopsi ide-ide dari area lain meliputi optimisasi, evolutionary computing, teori informasi, pemrosesan sinyal, visualisasi dan information retrieval. Gambar 1 di bawah ini menunjukkan hubungandata mining dengan area-area lain.

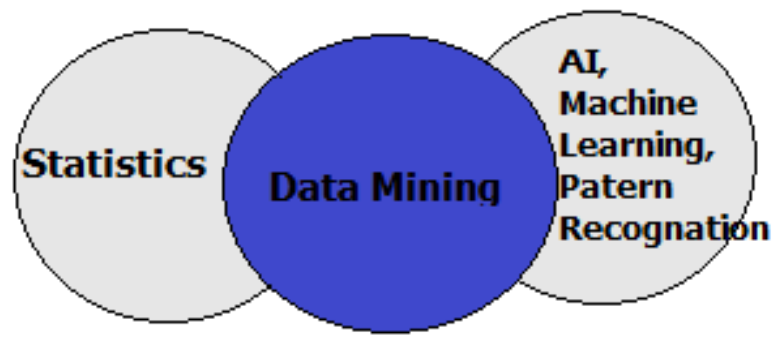

\section{Database Technology, Parallel Computing, Distributed Computing}

Gambar 1

Data mining sebagai pertemuan dari banyak disiplin ilmu

Ada beberapa penelitian sejenis yang pernah dilakukan oleh peneliti dari berbagai institusi akademik. Eni Irfiani dari Universitas BSI dengan judul Prediksi Keluhan Pelanggan Pada Apartemen Menggunakan Algoritma C4.5. Dalam penelitiannya Algoritma C4.5 digunakan untuk mengukur prediksi tingkat keluhan penggan yang telah menyewa sebuah apartemen dengan menggunakan 164 data sample hotel dengan 5 variable yaitu Kewarganegaraan, Status Pernikahan,Jumlah Penghuni, Jenis Unit,Label. Adapun hasil kesimpulan yang didapat adalah tingkat akurasi dengan nilai $75 \%$ (Irfiani, 2014). 
Literatur berikutnya Penelitian dengan judul Klasifikasi Pengaduan Masyarakat Menggunakan Nive Bayes Berbasis Seleksi Atribut Information Gain yang dilakukan oleh Alter Nasarudin dan Purwanto dari Jurnal Teknologi Informasi Udinus, Volume 14 Nomor 2 tahun 2018. Pada penelitian ini fokus pada objek terminal Jombor di D.I. Yogyakarta. Dalam penelitian ini menggunakan sejumlah 60 data testing dan diperoleh nilai akurasi sebesar 86,67\% (Lasarudin \& Purwanto, 2018).

Berbekal dari beberapa literatur itulah penulis jadikan sebagai referensi dalam melakukan hipotesis (Abdurrahman \& Muhidin, 2011). Adapun tujuan dari penelitian ini adalah mengukur seberapa tingkat efektifitas dari aduan masyarakat kepada pihak pemerintah yang dalam hal ini ditangani oleh satuan polisi pamong praja (Sat Pol PP) kabupaten Tegal. Sehingga dengan adanya penerapan kebijakan ini dapat mampu meningkatkan kinerja serta layanan kepada masyarakat hal inipun akan berdampak pada terciptanya suasana yang aman dan nyaman dalam masyarakat, rasa keadilan (Saggaf, Said, \& Saggaf, 2018).

\section{Metode Penelitian}

Metode pengumpulan data yang digunakan dalam penelitian ini adalah pendekatan kuantitatif dalam menganalisa keefektivitasan aplikasi pengaduan online. Metode yang digunakan dalam penelitian ini adalah Decision Tree Algoritma C45 untuk mengukur tingkat efektifitas aduan warga berbasis online (Sugiyono, 2017).

Tahapan-tahapan eksperimen yang sudah dilakukan dalam penelitian ini adalah (Mardi, 2017) :

a. Menyiapkan data sheet

b. Processing data dengan mereduksi data-data yang kosong

c. Melakukan eksperimen menggunakan metode C45 dengan menggunakan software Rapidminer

d. Menghitung keakurasian data dengan menggunakan metode $\mathrm{C} 45$

e. Menganalisa hasil dari keakurasian metode $\mathrm{C} 45$

Memberikan kesimpulan

Dalam melakukan penelitian tentunya memerlukan desain rancangan yang digunakan sebagai pedoman dalam melakukan proses penelitian. Desain penelitian bertujuan untuk memberi pegangan yang jelas dan terstruktur kepada peneliti dalam melakukan penelitiannya. Berikut ini lngkah-langkah yang dilakukan dalam penelitian. 


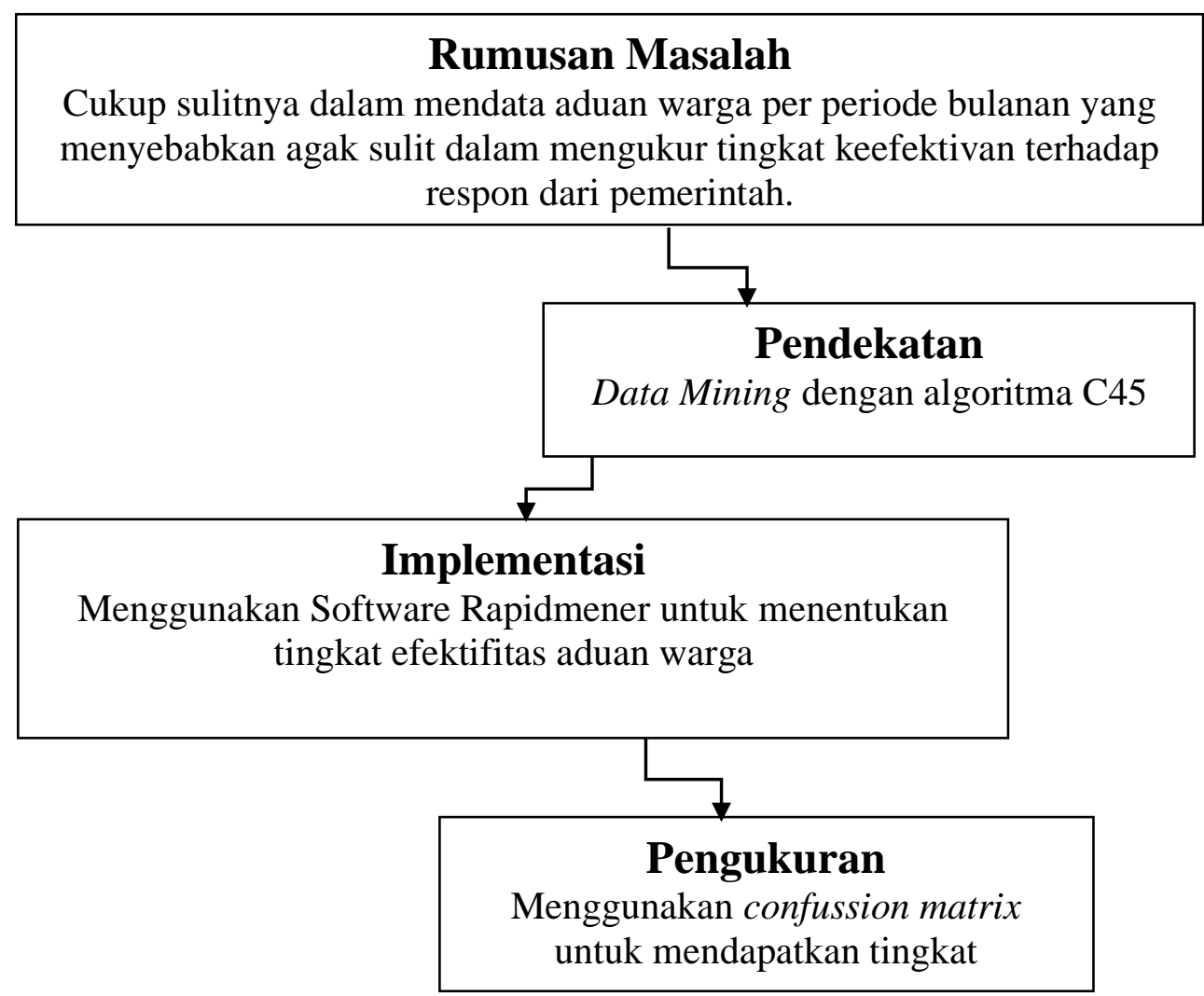

Adapun tahapan dari penelitian ini adalah sebagai berikut:
Tahapan
Luaran
Indikator

\section{Metode Pengumpulan Data}

Pengumpulan Data

Aduan Warga
Data aduan warga dari

Januari hingga

Oktober 2020.

Mendapatkan data aduan warga dari Satpol PP Kabupaten Tegal

Mendapatkan data utuh yaitu waktu dan tempat pengaduan, profil pelapor dan terlapor, deskripsi aduan, respon, rapat koordinasi dan penyelesaian.

Data Reduction

Mengeliminasi record kolom rapat koordinasi, profil pelapor dan terlapor

Mendapatkan data yang valid yaitu data yang tidak mempunyai nilai kosong 
Fahrudin dan Sugiarto

3. Perancangan Algoritma

Analisa Masalah dan

Studi Pustaka

Identifikasi masalah

Teori pendukung

yang ada dan

pengembangan teori

yang sesuai dalam

menyelesaikan suatu

masalah

Desain Algoritma

Memilih dan

Keseuaian design

perancangan

algoritma dengan

algoritma yang sesuai

kebutuhan sistem

dengan permasalahan

dalam penyelesaian

dan kebutuhan sistem

masalah

4. Sampling dan Implementasi Algoritma

Pengambilan

sample data

Penerapan algoritm

C45

\section{Pengujian dan Evaluasi}

Pengujian dan

evaluasi
Melakukan sampling

data dengan

menggunakan random

sampling dengan

komposisi data

training $100 \%$ dan

data testing $20 \%$ dari

data valid yang

didapat

Menerapkan

algoritma $\mathrm{C} 45$ dengan

Software Rapidminer

Menguji dan

mengevaluasi

penerapan model $\mathrm{C} 45$
Mendapatkan data

training dan data

testing
Mendapatkan graph pohon keputusan dan variabel penentu tingkat efektifitas aduan warga

Mendaptkan nilai akurasi klasifikasi algoritma $\mathrm{C} 45$ dan tabel confusion

matrix

\section{Hasil dan Pembahasan}

Dalam aduan warga hal yang cukup menjadi perhatian adalah tingkat partisipasi warga sebagai pihak informan, respon dari pemerintah serta tingkat penyelesaian dari aduan. Selama ini data aduan berupa berkas tertulis yang seringkali riskan hilang ataupun rancu dalam pendataannya. Sehingga cukup sulit dalam mengukur tingkat keefektifan dari aduan warga tersebut. Oleh karena itu perlu adanya pendataan secara komputerisasi secara online dan teknik pengukuran dengan menggunakan sebuah metode yaitu Decision tree dengan algoritma C4.5.

1. Hasil Pre-processing 
Pada penelitian ini menggunakan dua langkah pre-processing yaitu data intergration dan reduction.

1) Data Integration (proses penggabungan dari database yang berbeda)

Data set pada peneltian ini adalah database aduan dari bulan Januari hingga

Oktober 2020

2) Data reduction

Mereduksi atau menghilangkan atribut yang tidak diperlukan akan tetapi tidak mengurangi penyajian analistiknya.

2. Langkah Reduction Data :

Membuat Repository (create repository)

- Data

- Proses

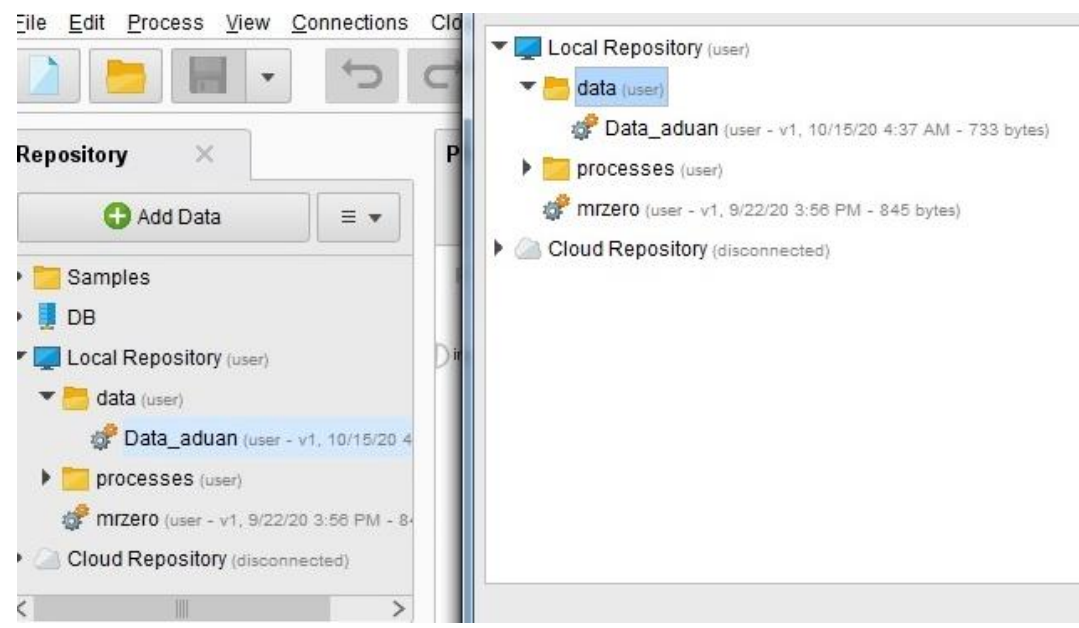

Gambar 2

Membuat repository data
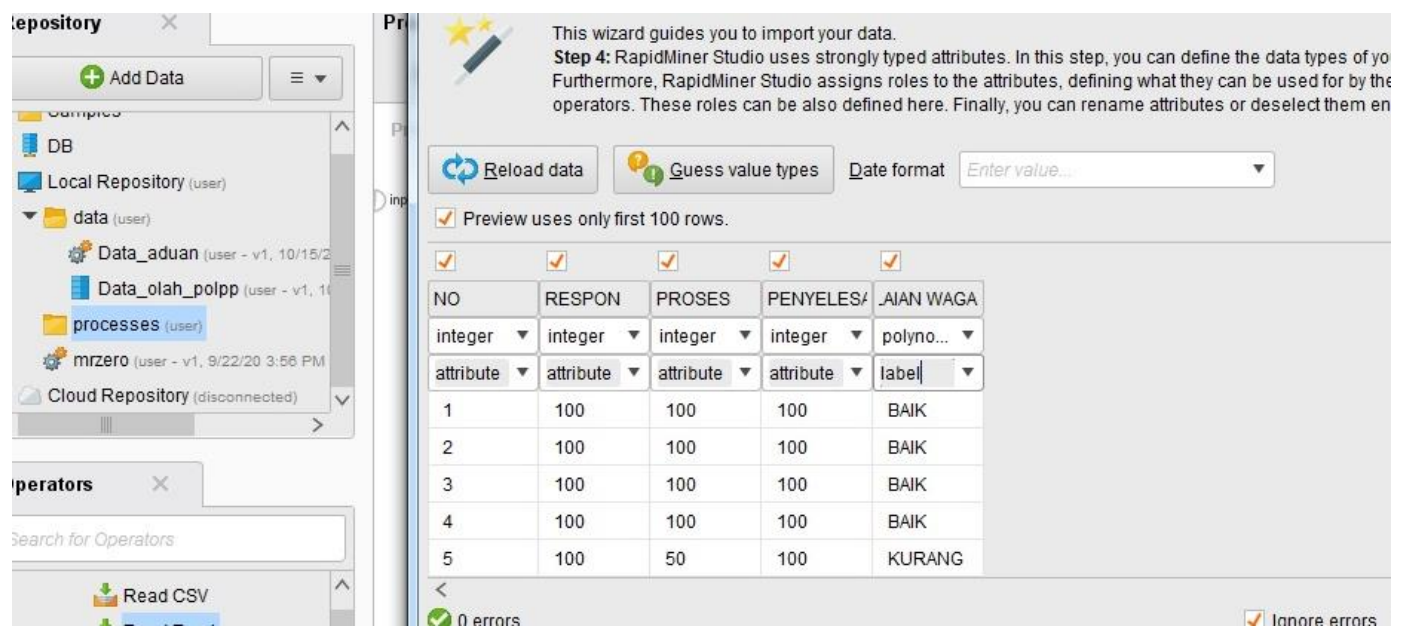

\section{Gambar 3}

Pemilihan atribut data 
Fahrudin dan Sugiarto

\begin{tabular}{|c|c|c|c|c|c|c|}
\hline Name & $p \&$ tige & Wasing & sesuses & Fant (5/5 a aributan) & Seureh for Astroulese & $\mathbf{P *}$ \\
\hline$\checkmark$ no & Intwoger & - & 1 & Nos & 5.500 & \\
\hline$\checkmark$ RESPON & Integer & - & 100 & $\operatorname{Mon}_{100}$ & 100 & \\
\hline$\checkmark$ PROSES & Irteger & - & so & $\operatorname{Man}_{100}$ & 95 & \\
\hline$\checkmark$ penyelesalan & integer & • & 100 & 100 & 100 & \\
\hline$\checkmark$ PEDILALAN WAGA & Potrominal & - & $\begin{array}{l}\text { Lum } \\
\text { RURANG (1) }\end{array}$ & BaAK (9) & $\begin{array}{l}\text { Volve } \\
\text { BAK (9) }\end{array}$ & NURAW \\
\hline
\end{tabular}

Gambar 4

Memfilter data setting yang missing dan Data Statistik

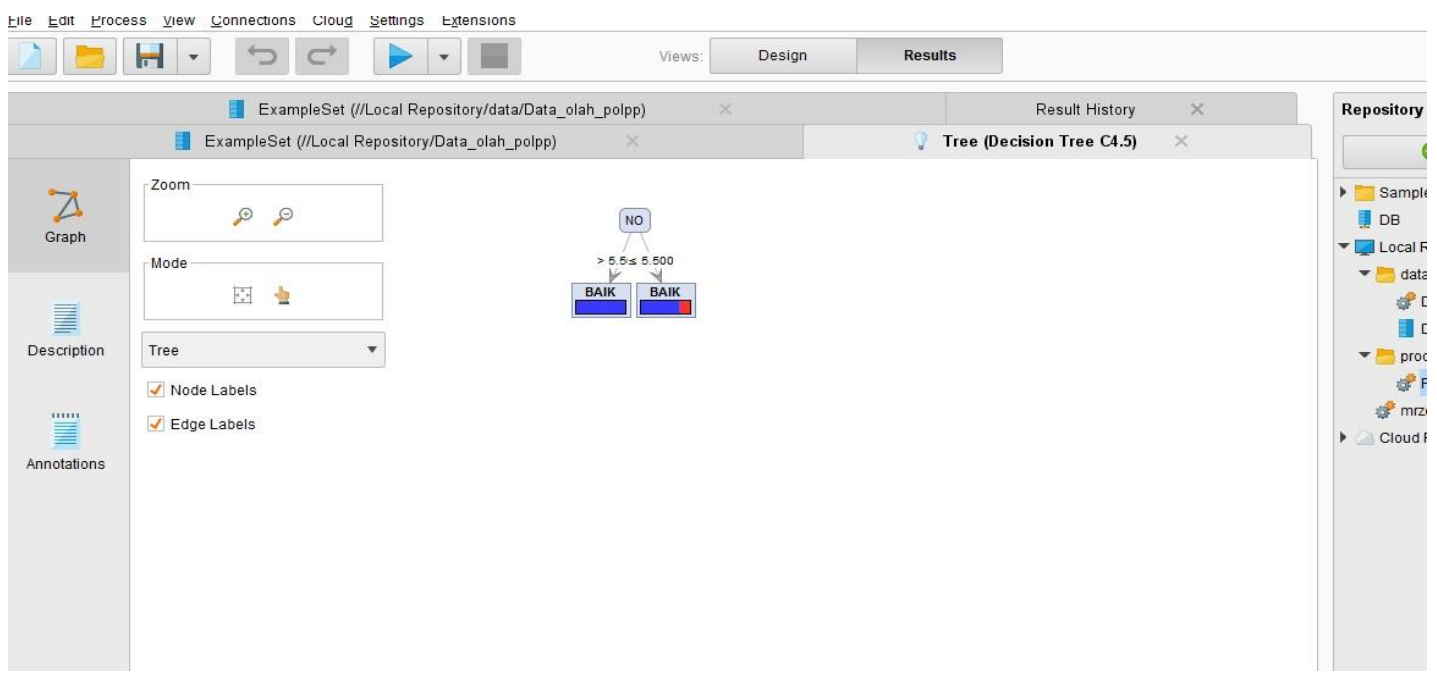

Gambar 5

Pohon keputusan algoritma decesion tree $\mathrm{C} 4.5$

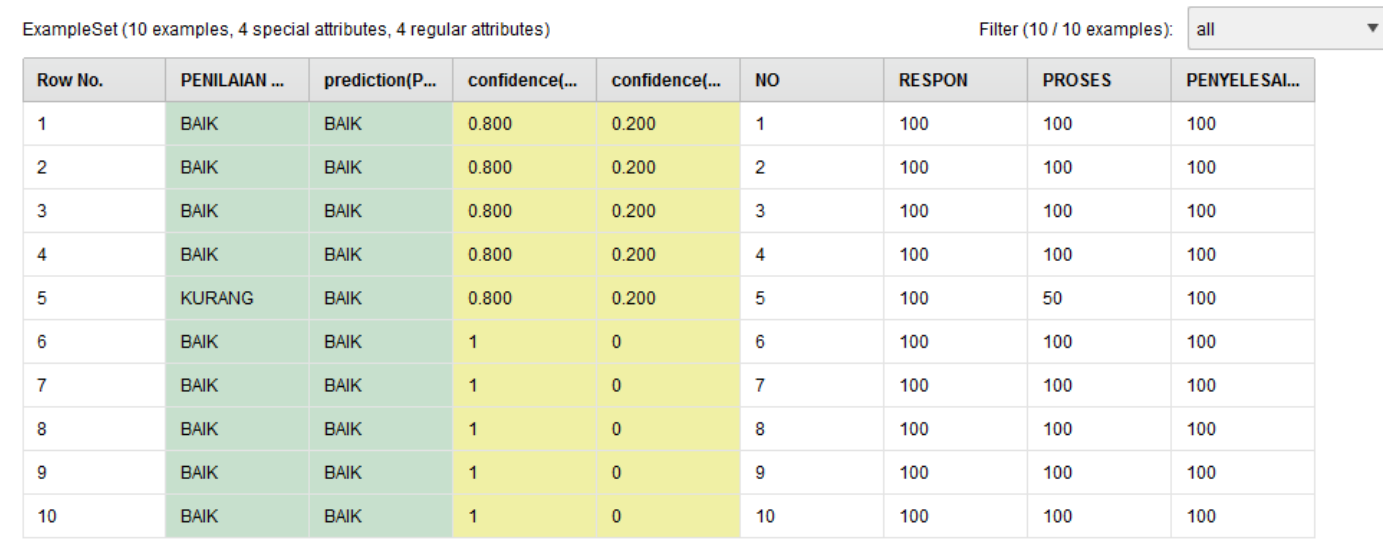

Gambar 6

Hasil data setelah di testing 


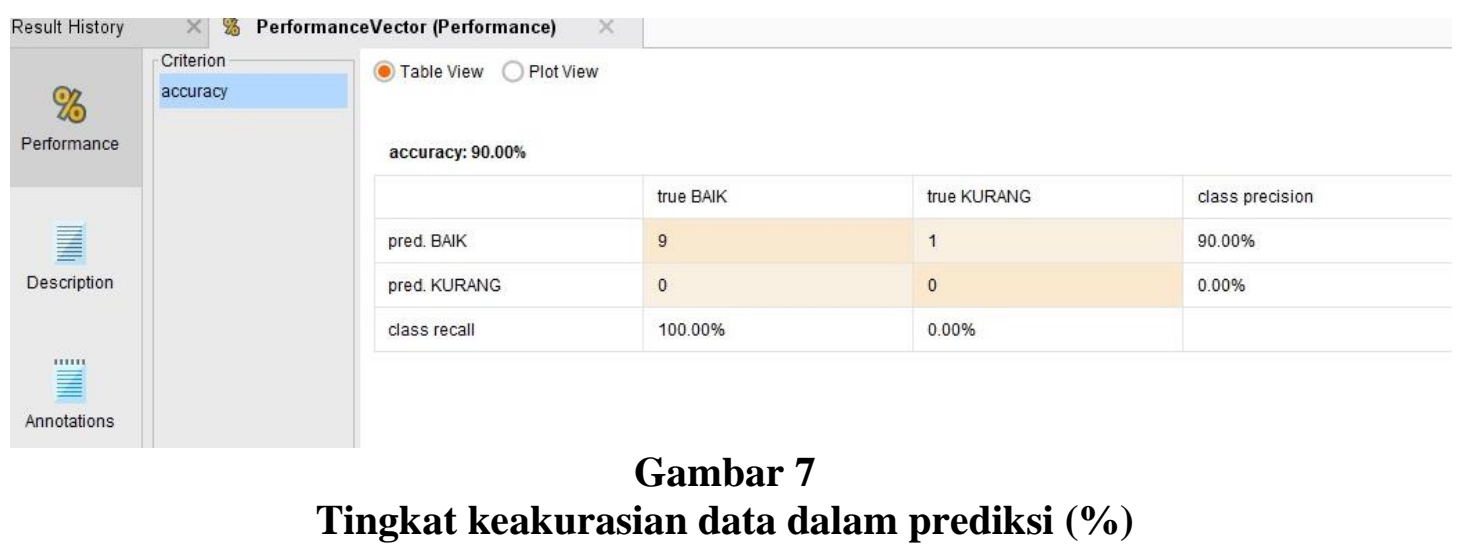

Pengujian di ukur dengan menggunakan confussion matrix (Vulandari, 2017) untuk mengukur performa keefektifan aduan warga dengan klasifikasi baik dan kurang adalah $90 \%$.

\section{Kesimpulan}

Dalam melakukan penelitian ini, penulis menggunakan 1 special atribut (atribut penilaian_warga) dan 3 atribut regular (respon, proses dan penyelesaian), data set warga periode bulanan dari Januari hingga Oktober 2020 yang diolah menggunakan software rapidminer-studio-9.7.2. menggunakan algoritma decision tree C4.5 dengan output yang terbentuk ialah klasifkasi berupa pohon keputusan (decision tree).

Algortitma C4.5 terbukti dapat digunakan dalam mengukur tingkat nilai akurasi sebanyak $90.00 \%$, dengan presisi kurang 10\% dan Baik 100\%, Class recall Kurang $100 \%$, dan recall Baik $90 \%$. Pengujian dengan rapidminer terbukti efektif dan fleksibel dengan hasil perhitungan yang tepat. 


\section{BIBLIOGRAFI}

Abdurrahman, Maman, \& Muhidin, Sambas Ali. (2011). Panduan praktis memahami penelitian. Bandung: CV. Pustaka Setia.

Etkisyan, Johan Arifin, \& Manar, Dzunuwanus Ghulam. (2018). Pengelolaan Tindak Lanjut Pengaduan Masyarakat Pada Siaran "Kabar Bupatiku” Di Kabupaten Tegal. Journal of Politic and Government Studies, 7(2), 91-100.

Irfiani, Eni. (2014). Prediksi Keluhan Pelanggan Pada Apartemen Menggunakan Algoritmac4. 5. Paradigma-Jurnal Komputer Dan Informatika, 16(2), 13-20.

Jiawei, Han, \& Kamber, Micheline. (2001). Data Mining: Concept And Techniques [M].[S. 1.]. America: Morgan Kaufmann Publishers, 223-224.

Lasarudin, Alter, \& Purwanto, Purwanto. (2018). Klasifikasi Pengaduan Masyarakat Menggunakan Naive Bayes Berbasis Seleksi Atribut Information Gain. Cyberku Journal, 14(2), 59-72.

Mahmudi. (2013). Manajemen Kinerja Sektor Publik. Yogyakarta: Sekolah Tinggi Ilmu Manajemen YKPN.

Mardi, Yuli. (2017). Data Mining: Klasifikasi Menggunakan Algoritma C4. 5. Edik Informatika, 2(2), 213-219.

Napitupulu, Paimin. (2007). Pelayanan publik \& customer satisfication. Bandung: Penerbit Alumni.

Prasetyo, Eko. (2012). Data mining konsep dan aplikasi menggunakan matlab. Yogyakarta: Andi.

Ratminto, Atik Septi Winarsih. (2005). Manajemen pelayanan. Yogyakarta: Pustaka Pelajar.

Saggaf, Said, Said, Muhammad Mario, \& Saggaf, Widiawati Said. (2018). Reformasi Pelayanan Publik di Negara Berkembang (Vol. 1). Sah Media.

Sugiyono. (2017). Metode Penelitian Pendidikan: Pendekatan Kuantitatif, Kualitatif, dan $R \& D$. Bandung: Alfabeta.

Suntoro, Joko. (2019). Data Mining: Algoritma dan Implementasi dengan Pemrograman PHP. Bandung: Elex Media Komputindo.

Vulandari, Retno Tri. (2017). Data Mining Teori dan aplikasi Rapidminer. Surakarta: Penerbit Gava Media. 